UDK 37.015

Деркач Л.М.,

доктор психологічних наук, професор, Дніпропетровський гуманітарний університет (м. Дніпро, Україна)

Derkach L.M, Ph.D in Psychology, Professor Dnipro Humanitarian University (Dnipro, Ukraine)

\title{
UKRAINE'S INTEGRATION INTO GLOBAL AND EUROPEAN EDUCATIONAL SPACE: PROBLEMS, CHALLENGES AND PERSPECTIVES
}

Зростаючий вплив Болонського проиессу на вищу освіту Украӥни викликав зачікавленість з приводу його досягнень та недоліків на шляху інтеграиії в світовий та Європейський освітній простір. Метою статті $\epsilon$ визначення та аналіз етапів, процесів та заходів, які вплинули на реалізацію Болонської моделі в країні з погляду вітчизняних та зарубіжних вчених. 3 поданням та аналізом необхідних заходів, законів та перспективних змін, ми намагаємося показати труднощі та проблеми, які можливо подолати.

Ключові слова: вища освіта Украӥни, Болонський прочес,експертна очінка вітчизняних та зарубіжних вчених, модернізація, досягнення, недоліки, виклики, перспективи.

The growing influence of the Bologna Process on Higher Education of Ukraine has raised concerns about its advancements and failures on the way of integration into global and European educational space. The aim of the given paper is to outline and analyze the steps, processes and measures which influenced the implementation of the Bologna model in Ukraine as viewed by native and foreign scholars. With presenting and analyzing the necessary measures, laws and perspectives of changes we try to show the difficulties and problems which the country perhaps has to overcome.

Keywords: higher education of Ukraine, Bologna Processes, domestic and foreign expertise, modernization, advancements, drawbacks, challenges, prospects.

Introduction. With 2018 marking the transition of Ukrainian state education policy from information-based structure to knowledge-based one, it is of vital importance to evaluate the impact of Bologna Process reforms on Ukrainian higher education system. By now, the country faces urgent tasks of national identity formation and nation building where education is central in 
addressing these goals in the context of entering European integration and globalization educational space.

The framework and the shift in integration perspectives that has occurred over the last two decades, referring the state and prospects of educational development in Ukraine, offers a potentially powerful venue for improving quality higher education in this country.

It is common knowledge, that successful transfer strategies provide the tremendous increase in international links in higher education in partnership with innovators, academics, thought-leaders and enterpreneurs to develop innovative solutions, products and services $[1 ; 2 ; 14 ; 15 ; 16 ; 18 ; 23]$. With all above mentioned, it is crucial to answer the questions and consider the problems and challenges regarding Ukraine's participation in the Bologna Process and EHEA:

- has it resulted in more transparency in Ukrainian higher education?

- what advancements have been achieved and drawbacks have been singled out?

- what problems and critical challenges do still remain?

- On what policy actions and programs do we need to focus more directly to offer creative and competent solutions and measures to successfully enter the global and European scientific space?

In view of this, the aim of the given article is to analyze the impact of Bologna Process and EHEA educational reforms on Ukraine's integration of successful policies and strategies towards entering the global and European educational space, as viewed by native and foreign experts.

With this aim in purpose, we shall address the recent publications (20102017) of educational leaders, academics, professionals, researchers, entrepreneurs, practitioners and top-performing students both in this country and abroad. Alongside with this, we are pretty aware of diversity opinions which provides pros and cons in evaluating process, on the one hand. On the other hand, advances and drawbacks of education in Ukraine, as viewed by representatives of various cultures, countries, paradigms, universities, etc. show that advancing critical challenges and problems singled out will take place against the background of major educational changes, we believe.

Results. In light of this, it is relevant to review some of the major regulatory and analytical documents which were adopted by Ukraine, changing state education policy in the context of globalization and European integration.

Since 1991, when Ukraine gained its independence, the creation of the national education started with the adoption of the Laws "On Education and Science and Scientific and Technology Activities" (1991) under the auspices of the National Academy of Educational Sciences of Ukraine (NAES) which became the leading research center on the way of profound changes of national system of education. The next period of modernization of national education policy was marked by the adoption of the innovational Law of Ukraine " On Higher 
Education" (2015) on the basis of the Bologna Process in creation of the European Higher Education Area" [16,5], as well as the Law "On Science, Scientific and Technology Activities" was also adopted the same year (2015). And finally, in the period of the 2015-2016 the Draft Law “ On Education" was submitted to the Parliament, and is currently undergoing the trial period [16,5].

In sum, Laws of Ukraine on educational transformations outlined the urgent tasks and regulations aimed at strengthening and changing public attitudes "...towards education and its research orientation in the prospect of reforming the educational sphere, as required by the European integration and globalization challenges of the XXI century, investigative and innovative character of civilization progress"...[16,5]. Additionally, in November, 2017, Gotheborg the European Commission presented the innovative approach, mechanism and measures to creating a European Education Area by 2025 to its Member States[21].

In terms of defining the problem under the discussion, the future horizons of European education as synergy of science, education, technology, economy which underlie global development community, were offered by the European Commission. In the Ukrainian context, we suppose, it is a new step towards the debate regarding key problems of the European future in education and culture, and Ukraine, in particular. It sets its vision for how we can create a European Education Area by 2025 [21]. The ideas suggested there, are of crucial importance for Ukraine as they outline the ways to harness the full potential of education and culture as drivers for job creation, economic growth and social fairness as well as a means to experience European identity in all its diversity. According to the European Commission[21] a European Area of Education should include:

- $\quad$ making mobility a reality for all;

- the mutual recognition of diplomas;

- greater cooperation on curricula development;

- improving language learning;

- $\quad$ promoting lifelong learning;

- mainstreaming innovation and digital skills in education;

- $\quad$ supporting teachers;

- $\quad$ creating a network of European universities;

- $\quad$ investing in education;

- $\quad$ preserving cultural heritage.

Thus, EHEA regulatory documents will help all the European educational community to navigate challenges and to take advantage of educational change and advance on global level that will improve living standards of people.

As we have already mentioned, the current research is aimed at presenting diverse views of native and foreign experts on evaluating the outcomes and failures of Ukraine's education reform with regard to the problems and obstacles. 
The impact of the Bologna Process on formation, implementation and modernization of the national education policy (2003-2013) was marked by " increasing spectrum and strength of the transformational impact of European integration and world globalization", states V.Kremen[16].

As we reflect on hard-fought progress in the Ukrainian educational space $[16,10]$ regarding the analysis of advances and losses in the process of education reform, we have an opportunity to make important changes in how we approach development.

Let us dwell on the evaluation of the achievements and drawbacks since 2003 till 2017. We shall start with one of the comprehensive sources - the National Report on the State and Prospects of Education Development in Ukraine published in 2017[16]. It contains the analysis of the progresses and failures of national development changes over the last 25 years; reasons that provoked the pressing issues and challenges. It also suggests the scientifically grounded proposals concerning the ways of domestic education modernization in the context of globalization, European integration and national self-identification. According to the report, " ... it is important to evaluate objectively the achievements and losses of the past twenty -five years" $(16,10)$. The most important include the following gains:

- development of new methodology of Ukrainian education development;

- creation of new legal framework for education;

- defining the principles of equal access to quality education;

- formation of education content on the base of state standards;

- creation of scientific and methodological and largely programs and methodical resource for the transition to the 12-year comprehensive secondary education;

- $\quad$ transition to the variable education;

- use of new forms and technologies of control and evaluation of academic achievements, introduction of the external independent assessment;

- $\quad$ introduction of new methods of pedagogical and scientific and pedagogic personnel attestation;

- dissemination of new educational technologies;

- gradual transition to multi-way financing;

- creation of the national pedagogical press;

- development of professional associations.

Among other policy education dynamic changes, losses (as coined in the Report) in the process of education reform of higher education some are also described, namely:

- lack of systematic research-based ideology of education development;

- functions of VET institutions and vocational schools, colleges under the new market conditions, innovative economy are still being undefined; 
- due to the weak control at the center and at the local positions of the quantitative growth of higher education institutions, there appeared some risks that youth might obtain poor quality of education, thus the image of Ukrainian higher education abroad has deteriorated;

- $\quad$ transition to the next stages of education system modernization without proper monitoring as a preliminary condition;

- teacher education became the outsider for the higher education; the teacher is not formed as the subject of current values;

- $\quad$ aging of logistics.

Overall, the Report states in conclusion: " These and other mentioned areas of education have not yet accrued systematic, interconnected nature and, therefore, do not form a coherent state policy in education" $[16,11]$.

Similarly, publication edited by Yevhen Nikokaiev in the year 2017, and prepared by authors from universities, Ukrainian and German academic institutions with the participation of Educational Trends analytical agency, has also covered achievements and failures, controversies of education reform efforts in Ukraine during 1993 - 2013[12]. Agenda for reforms, as seen by P.Kostrobiy and Y.Rashkevych [13], set forth for conceptual fundamentals and instruments in order to change the old educational paradigm of this country. In conclusion they state that "... despite certain successes....education and science in Ukraine were not united, the third cycle of higher education (compatible with European programs of doctoral education) was not introduced, the idea ESTS and competentbased approach did not get inside the process of creation and implementation of study programs, academic autonomy stayed a dream, no real steps for assuring higher education quality were taken. The gap between the Ukrainian national higher education system and EHEA was on the rise" $[13,20]$. The next influential source of information for our literary review is a profound article written by Professor Sofiya Nikolaeva, a famous expert in Methods of Teaching [17]. The researcher presents a thorough, detailed analysis of four steps ( stages) of the Bologna Process in Ukraine's implementation, making use of various methods and techniques of data collection, summing up pros and cons at each stage within the period of 2005 - 2015 years. The author resumes that: “... Ukraine has achieved a lot, but many of the key issues need solution" [17,66]; and furthermore, " Much has been done. Something succeeded, something needs to be improved and implemented "[17,73].

Looking back, Professor Nikolaeva refers to the Yerevan Communique (May 2015) where key priorities for Ukraine by 2020 were put forward, namely:

- enhancing the quality and relevance of learning and teaching;

- fostering the employability of graduates throughout their working lives;

- making the systems more inclusive;

- implementing agreed structural reforms[17]. 
Additionally, from the author's point of view, of utmost importance is " to harmonize the relevant national documents with the Revised Standards and Guidelines for Quality assurance in the European Higher Education Area (ESG)[18]; the European Approach for quality Assurance of Joint Programs and revised ECTS Users' Guide, as an official EHEA document" [17,73].

So, if one attempts to compare facts in common and differences mentioned above by educationalists, it is possible to note that considered advancements are the matter of almost the unity of outlooks. At the same time, failures which were singled out, in our view, deal with different spheres of the educational reform and its changes as the result.

In our point of view, it is desirable to concentrate attention on the problems of labor market today, its needs and requirements and strengthening career guidance of students from starters to graduates. It is a topical problem for Ukraine and little has been done in this area. As our literary review shows, employability rate of recent graduates, despite some progress, has persistent regional differences, and is still limited. To illustrate this, we set an example in which Master's graduates $(\mathrm{NO}=86)$ from different regions of the country were asked to fill in the questionnaire (20 questions). The goal was to examine perspectives and problems on their forthcoming employment. Tracking surveys of graduates, we perceived that no reliable data on job market issues today are available for them, and making educational mobility a reality for them, as well. To make depth a more central element in educational policy formation, it is desirable among selected policy priorities include mobility opportunities for students regarding their training and employment. Navigating the dynamic implications of educational changes in Ukraine, research and theory, migration processes[8;9;10], it will also require sound policies informed by a long-run perspective tailored to a nation's educational context on the job vacancies, we believe. We would attempt suggesting, in this respect, the role of three strategic priorities to advance development and educational changes, namely:

1) to grow economies in ways that are sustainable and create jobs in this country and a region, in particular;

2) to invest in students' and teachers' social and economic potential;

3) to ensure risks against rapidly changing market.

As we have already mentioned, the goal of our paper is to compare the evaluation of history and current state of tertiary education in Ukraine by views of insider's (native) and outsider's ( foreign) perspective. The comparative analysis demonstrates that views outside are likely different from inside ones. A wellknown Publication House Springer is also famous for issuing research book series "Globalization, Comparative Education and Policy Research" [14], and provides a global overview from 2008-2017 of developments and changes in policy and comparative educational research during the last decades. Referring educational reforms in Higher Education of Ukraine, it is stated that " The awakening of the civil society in Ukraine has called national universities to play a major role in 
social and economic transformations aimed at eliminating post-colonial legacies and accelerating the country's European integration" [14,133]. Alongside with this , it is concluded that, '...the higher education system of Ukraine used to be on periphery of " knowledge empires" and development" [14,133]. Developing the qualitative analysis of the theme, one of the contributors of the 2017 issue series suggests: "Disruptive innovation strategies in post-revolutionary Ukraine call for large scale and long-term engagement of foreign experts in Ukrainian universities to stimulate local students and the young professoriate to adopt radically different forms of inquiry and learning in higher education $[14,146]$. According to the author, the foreign experts ".. are expected to become internal reform monitors, "movers and shakers"[ $[14,146]$. Pointing out to the risks of the educational reform, the analyst confirms that "...Ukrainians run a risk of setting their expectations too high, developing new types of dependencies and promoting uncritical elites that well erect new hierarchical and stratified forms and norms of higher education" $[14,146]$.

The same year (2016) the project "Higher Education Reforms Reinforcement in Eastern Partnership Countries" was implemented with the support of Eastern Partnership Civil Society Forum.[22]. The three partners of the project Belarus, Armenia and Ukraine examined higher education reform in light of Bologna Process as well as opportunities, obstacles, context [22].

Evaluating development results in the period of 2002-2014, it was concluded that it "... was filled in a number of not very successful education system modernization attempts" [22,15]; while the period of higher education transformations after March 2014 was intensified, 'The Bologna standards implementation process became more consistent" [22,15]. Moreover, the " Introduction of new standards changed a lot in existing before education system but also generated natural resistance .... In particular, the regular aspirantura was practically replaced by Doctor of Philosophy Program...such program needs to be licensed. Such radical changes came as a shock for research institution..." [22,15]. And further on: " The National Qualification Framework implementation hadn't always gone smoothly as well. In some ways, its implementation totally failed" $[22,16]$. As for the problems and challenges it was recommended for Ukraine by the partners of the project:

- To accelerate the development of complex regulatory documents, which will allow fast and with minimal losses to proceed Ukraine higher education "reboot" in accordance with European standards, approaches and recommendations;

- Approbation and further development of innovative model of state funding for education and search for optimal ratio of its configuration with possible corporate funding for education;

- To use all possibilities for developing National Qualification system to ensure efficient and effecting relations between business, higher 
education and labor market in order to achieve high level of graduates employment according to their interests and skills as well as social needs.

Quite different aspects of the educational reform vectors are treated in the research by Denisova-Schmidt[5] on challenges of academic integrity in higher education in the year 2017, aimed at revealing causes of Ukraine's endemic higher education corruption .

It is worth while mentioning, that the foreign scholar Denisova-Schmidt of the University of St .Galen ( Switzerland) has printed several articles [6;7] on the major outcomes of the Ukrainian educational reform, focusing her attention on the corruption problem that hinders progress and change. The empirical data were obtained in an experimental evaluation of an anti-corruption intervention among Ukrainian University students[7].

The same idea is supported in the research conducted by Chapman and Linder [4] in 2016, where investigators examine the degrees of integrity and the threat of corruption in Higher Education.

One more investigation on the Bologna Process in Ukraine was carried out by Covacs [3] in 2014. The author presented and analyzed the necessary measures, laws and orders in the attempt to show the difficulties and problems which Ukraine as a young nation has to overcome. She concludes that "One of the most important problems is the unfinished and insufficient system with regards to the implementation of the reform objectives" [3, 321].

In the qualitative analysis of similarities, divergence, and incapability in the Bologna Process reform implementation by the former-socialist countries, realized by Soltys [20], the attention is paid to the problems that are typical of all the former-socialist countries. According to Soltys, the major problems and obstacles are connected with "The overemphasis on bureaucratic checks and controls of the Bologna Process negates two important aspirations of the Bologna Process: university autonomy, empowerment of faculty, and development of local communities....the free flow of international knowledge" [20,321].

In light of stated above, current problems of Ukraine's integration into the global and European educational space, we studied the earlier published works from 2005-2012, and major advances and failures viewed by foreign scientists. The position of the American researcher Filiatreau [11] who analyses the impact of the Bologna Process reforms on Ukrainian educational policy during 20052009 period is coined like this: " Having joined the Bologna process in 2005, Ukraine hopes to strengthen its relationships with the EU through participation in European Commission-sponsored projects, and to increase its own research capabilities and build the capacity of its higher education system. However, after the collapse of the Soviet Union, higher education has become one of the most corrupt areas in Ukraine"[11, 49].

One more aspect in the adoption of the Bologna Process at a Ukrainian University, namely, the organizational culture of academic staff was presented 
by Shaw et al[19]. Educationalists resume: "We found that instructional and institutional innovations were successfully implemented only to the extent that they were integrated with the existing pattern of values and beliefs held by faculty"[ 19,1$]$.

Conclusions. Thus, there are many reasons to believe that foreign experts [3-7,11-, 14-15, 19-23] , evaluating the context of Ukraine's policy educational reforms and national strategic objectives of entering the global and European educational space, were eager to draw the Ukrainian's community attention to the vital, unsolved problems, challenges and perspectives to overcome obstacles and failures on the way of changes. As Filiatreau concludes, "...many Ukrainian educational leaders and researchers have a wealth of ideas and experience to move the higher education reform in the direction that would benefit the country as whole and its people"[11,59].

What seems clear, however, is the urgent need to proceed from a rhetoric of change to the rhetoric of creative moves grounding on national values and national educational context and achievements obtained. The main open questions deal with four priorities, in our view, namely:

- Ensuring that higher education institutions of Ukraine contribute to innovations [10];

- Promoting excellence in skills development and tackling future skills mismatches [8];

- Supporting effective and efficient tools for getting universities and employers to work together [9];

- Eliminating the gap between student training and business needs.

Further Research. All the mentioned issues above, offer ample opportunities for scholarly investigation. Another unanswered question concerns the career guidance and planning of University students and graduates in the European and global educational contexts.

\section{REFERENCES}

1. Altbach, P. (2016). Global Perspectives on Higher Education. Baltimore: John Hopkins University Press.

2. Carnoy, M. (2013), Prashant, L., Dobryakova, M. ( 2013). University Expansion in a Changing Global Economy; Triumph of the BRICK's? Stanford: Stanford University.

3. Covacs, K. (2014). The Bologna Process in the Ukraine. In: The Bologna Process in Central and Eastern Europe, edited by T.Kozma et al, 321-353.

4. Chapman,D.W., \& Linder,S. ( 2016). Degrees of Integrity: The Threat of Corruption in Higher Education. Higher Education, 41(2), 247-268.

5. Denisova-Schmidt, E., Prytula, Y. (2017). Ukraine: Endemic Higher Education Corruption. International Higher Education, 90, 16-18. 
6. Denisova-Schmidt, E .(2017). The Challenges of Academic Integrity in Higher Education: Current Trends and Outlook, CIHE Perspectives, Vol.5. Boston; Boston College.

7. Denisova-Schmidt, E., Huber, M., Prytula, Y. (2015). An Experimental Evaluation of an Anti-Corruption Intervention Among Ukrainian University Students. Eurasian Geography and Economics, 56 (6), 713-734.

8. Derkach, L. Maksymenko, S. (2016). Psychological Literacy in Ukraine: Ways of Learning and Living. American Journal of Fundamental, Applied and Experimental Research. Ukraine and Ukrainians Abroad. Not for Profit Corporation. New York, N.Y,U.S.A:28-37.

9. Derkach, L. Minka, P. (2012). Ways of Learning and Living in Ukraine. Collective Monograph/ M.Giliberto, C.DellaAversano and F. Velicogna (Eds.). - PCP and Constructivism: Ways of Working, Learning and Living. Libri Liberi, Firerenze:547-554.

10. Derkach, L ( 2017).Innovative Universities in Ukraine: Perspectives and Solutions. American Journal of Fundamental, Applied and Experimental Research. Ukraine and Ukrainians Abroad. Not for Profit Corporation, New York N.Y. U.S.A:10-16.

11. Filiatreau, S (2011). Ukraine's Participation in the Bologna Process: Has it Resulted in More Transparency in Ukrainian Higher Education Institutions? International Research and Review: Journal of PHI Beta Delta Honor society of International scholars, vol.1, Issue 1, 2011, pp.49-60.

12. Higher education in Ukraine: Agenda for Reforms (2017); [edited by Yevhen Nikolaiev.- Kyiv: Konrad -Adenauer-Stiftung Ukraine Office, 2017.

13. Kostrobiy, P., Rashkevich, Yu.(2017). Ukrainian Higher Education in 1991-2013: Successes and Failures of the Reforms. In: Higher Education in Ukraine: Agenda for Reforms (2017); [edited by Yevhen Nikolaiev.- Kyiv: Konrad - Adenauer - Stiftung Ukraine Office: 15-21.

14. Kozma, T., Rebay,M., Ohidy, A, Szolar,E (eds.) (2014). The Bologna Process in Central and Eastern Europe. - Studien zur international vegleichenden Erziehungwissenschaft. Schwerpunkt Europa.- Studies in International Comparative Educational Science. Focus: Europe, Springer Fachmedien Wiesbaden.

15. Mihut, G., Altbach, P.G.,\& de Wit, H.(Eds.) (2017). Understanding Global Higher Education. Insights from Key Global Publications. Rotterdam: Sense Publishers.

16. National Report on the State and Prospects of Education Development in Ukraine/ National Academy of Educational Sciences of Ukraine; [ editorial board: V.G.Cremen ( head), V.I.Lugovyy (Deputy head), A.M. Gurzhii ( deputy head), O.Ya. Savchenko ( deputy head)], edited by V.G.Kremen. - Kyiv: Pedagogichna dumka, 2017. - $336 \mathrm{p}$.

17. Nikolaeva, S. (2015).The Bologna Process in Ukraine: The Decade Anniversary.- General and Professional Education, 4, 66-74. 
18. Oleksieyenko, A. (2016). Higher Education Reforms and CenterPeriphery Dilemmas: Ukrainian Universities Between Neo- Soviet and NeoLiberal Contestations. In: Zaida, J., Rust, V. (eds.) Globalization , Comparative Education and Policy Research, vol.15, Springer, Cham, 133-148.

19. Shaw,M., Chapman, D.W and Rumyantseva, L. (2011). Organizational Culture in the Adoption of the Bologna Process: A Study of Academic Staff at a Ukrainian University. Studies in Higher Education, 201,1-15.

20. Soltys, D. (2015). Similarities, Divergence, and Incapability in the Bologna Process Reform Implementation by the Former-Socialist countries: The Self-Defeat of State Regulations. Comparative Education, Vol.51, Issue 2, 179195.

21. Towards a European Education Area by 2025 (2017). Strasbourg, France http://ec.europa.eu.commission/news/towards-european-education-area2025-2017-nov-14_en

22. Yahorau, A., Antashkevich, S.(2016). Higher Education Reform in Light of Bologna Process: Opportunities, Obstacles, Context. Recommendations for Eastern Partnership Countries. Yerevan- Minsk- Kyiv. Eastern Partnership Civil Society Forum. Ministry of Foreign Affairs of the Czech Republic.

23. Zaida, J., Rust,V. (eds.). Globalization, Comparative Education and Policy Research, vol.15, Springer, Cham. 